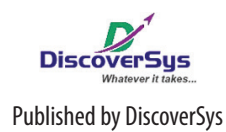

\title{
Pemantauan dan Pencegahan Penularan Virus Zika di Indonesia
}

\author{
Dewa Nyoman Wirawan ${ }^{1,2^{*}}$
}

${ }^{1}$ Program Studi Magister IImu Kesehatan Masyarakat Universitas Udayana,

${ }^{2}$ Bagian IImu Kedokteran Komunitas dan IImu Kedokteran Pencegahan Fakultas Kedokteran Universitas Udayana

*Correspondence to: Dewa Nyoman Wirawan, Program Studi Magister IImu Kesehatan Masyarakat Universitas Udayana, Bagian IImu Kedokteran Komunitas dan IImu Kedokteran Pencegahan Fakultas Kedokteran Universitas Udayana

wirawandewa48@gmail.com
Sama halnya dengan Virus Dengue dan Virus Chikungunya, Virus Zika juga ditularkan oleh nyamuk Aedes aegypti. ${ }^{1}$ Nyamuk ini biasanya hidup di daerah tropis dan sub tropis. Virus Zika pertama ditemukan pada seekor monyet resus di Hutan Zika, Uganda, pada tahun 1947. ${ }^{1}$ Virus Zika kemudian ditemukan kembali pada nyamuk spesies Aedes africanus di hutan yang sama pada tahun 1948 dan pada manusia di Nigeria pada tahun 1954. Virus Zika menjadi penyakit endemis dan mulai menyebar ke luar Afrika dan Asia pada tahun 2007 di wilayah Pasifik Selatan. Pada Mei 2015, virus ini kembali merebak di Brazil. ${ }^{2}$ Penyebaran virus ini terus terjadi pada Januari 2016 di Amerika Utara, Amerika Selatan, Karibia, Afrika dan Samoa. Pada Bulan April 2016 dilaporkan pula di Vietnam dan kemudian mewabah di Singapura dan Thailand. ${ }^{2}$ Sampai dengan tanggal 11 September 2016, sebanyak 329 kasus telah dijumpai di Singapura dan 8 diantaranya pada wanita hamil. Pada Bulan September 2016, Pemerintah Thailand mengumumkan bahwa telah dijumpai sebanyak 21 kasus di Bangkok dan semuanya dilaporkan karena penularan secara lokal. ${ }^{2}$ Di Indonesia, telah ditemukan virus Zika di Jambi pada tahun 2015 yang penularannya juga terjadi secara lokal karena orang yang terinfeksi tidak pernah bepergian keluar daerah tempat tinggalnya. ${ }^{3}$

Gejala-gejala orang yang terinfeksi Virus Zika antara lain: demam yang tidak begitu tinggi, ruam pada kulit, merah pada mata (conjunctivitis), sakit pada otot dan sendi, sakit kepala dan merasa lemas (malaise). Gejala-gejala ini akan menghilang dengan sendirinya dalam waktu 2-7 hari. Sama halnya dengan infeksi Virus Dengue, kebanyakan orang yang terinfeksi Virus Zika juga tidak menunjukkan gejala sakit (asimptomatis) tetapi bisa menularkan virus kepada orang lain. ${ }^{1}$

Perbedaan antara Virus Dengue dan Virus Zika adalah dalam hal komplikasi dan cara penularannya. Pada infeksi Virus Dengue, angka kematian dilaporkan sekitar 1-2\% sedangkan pada Infeksi Virus Zika belum dilaporkan adanya kasus yang meninggal, tetapi Badan Kesehatan Dunia (WHO) telah menyatakan bahwa Infeksi Virus Zika bisa menyebabkan terjadinya komplikasi pada syaraf yaitu terjadinya microcephaly pada bayi yang sedang dikandung dan Guillain-Barré syndrome (gejala-gejala kelainan syaraf pada kaki dan tubuh lainnya), yang bisa menyebabkan kelumpuhan bahkan kematian. ${ }^{1,4}$ Berbeda dengan infeksi Virus Dengue yang hanya melalui nyamuk, infeksi Virus Zika juga dilaporkan bisa menular melalui hubungan seksual karena virus dijumpai pada cairan sperma orang laki yang terinfeksi. ${ }^{1,4}$

Karena populasi nyamuk Aedes aegypti sangat tinggi di Bali serta wilayah lain di Indonesia, maka penularan Virus Zika di Bali/Indonesia bisa dipastikan juga akan terjadi sama halnya dengan negara lain seperti Vietnam, Thailand dan Singapura. Selain itu, seperti dikemukakan di atas Virus Zika juga telah pernah dijumpai di Jambi dan penularannya terjadi secara lokal. Karena itu, melakukan pencegahan penularan dari luar negeri ke Bali/Indonesia dengan memantau suhu tubuh di bandara pada orang-orang yang datang dari luar negeri tidak cukup untuk mencegah penularan karena sebagian besar orang yang terinfeksi tidak menunjukkan gejala (tidak demam), tetapi bisa menularkan virus di Bali/Indonesia.

Untuk mengetahui kemungkinan terjadinya penularan di Bali/Indonesia, maka satu-satunya cara yang bisa dilakukan adalah pemantauan atau surveilans. Surveilans bisa dilakukan secara paralel dengan surveilans Demam Berdarah Dengue yang telah dilaksanakan selama ini. Untuk menetapkan terjadinya infeksi Virus Zika, diperlukan pemeriksaan laboratorium. Di negara-negara maju, pemeriksaan dilakukan dengan nucleic acid testing (NAT). Karena biayanya cukup mahal maka untuk di Indonesia/Bali cara ini tidak memungkinkan untuk dilaksanakan. Cara yang lebih murah adalah melakukan pemeriksaan IgM pada darah pasien yang dicurigai dengan gejala-gejala seperti diuraikan di atas. Pemeriksaan IgM dilakukan dua kali, idealnya pemeriksaan pertama dilakukan 5 hari sejak demam dan yang kedua adalah 2-3 minggu setelah pemeriksaan pertama untuk mengetahui adanya kenaikan titer antibodi (IgM). Bila biayanya dirasakan cukup mahal, bisa dilakukan pemeriksaan secara sampling pada kasus-kasus yang dicurigai.

Upaya lainnya adalah meningkatkan awareness kepada masyarakat dan petugas kesehatan terhadap adanya kemungkinan penularan Virus Zika di Bali/Indonesia. Kepada petugas kesehatan perlu diberikan pemahaman bahwa bila dijumpai adanya infeksi Virus Zika maka diperlukan konseling yang 
memadai kepada pasien untuk tidak melakukan hubungan seks atau memakai kondom dengan istri/ suaminya atau pasangan seksualnya selama 60 hari guna mencegah terjadinya penularan melalui seksual. Bila istrinya sedang hamil maka dianjurkan untuk tidak melakukan hubungan seks atau secara konsisten memakai kondom selama masa kehamilannya. Sama halnya dengan pencegahan penularan infeksi Virus Dengue, pemantauan jentik nyamuk Aedes aegypti dan pemberantasan sarang nyamuk (PSN) amat perlu ditingkatkan.

\section{DAFTAR PUSTAKA}

1. World Health Organization. Zika Virus Fact Sheet. Geneva, 2016. Available online at http://www.who.int / mediacentre/factsheets/zika/en/
2. World Health Organization. Zika Situation Report. Geneva, 2016. Available online at http://www.who.int / emergencies/zika-virus/situation-report/21-july-2016/en/

3. Perkasa A, Yudhaputri F, Haryanto S, Hayati RF, Ma'roef CN, Antonjaya U, Yohan B, Myint KS, Ledermann JP, Rosenberg R, Poerws AM, Samsono RT Emerg Infect Dis. 2016 May;22(5):924-926. Doi: 10.3201/eid2205.151915.

4. Centers for Disease Control and Prevention. Information for Specific Groups, 2016. Available online at https://www. cdc.gov/zika/specific-groups.html

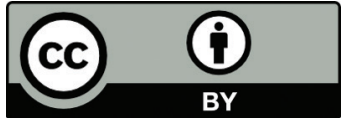

This work is licensed under a Creative Commons Attribution 